\title{
SOSIALISASI PEMANFAATAN LIMBAH RUMAH TANGGA SEBAGAI PUPUK CAIR DI DESA JANGO KECAMATAN JANAPRIA KABUPATEN LOMBOK TENGAH
}

\author{
Asniwati ${ }^{1}$ Aulida Silvy Azkia ${ }^{2}$ Raden Ratu Andriany Candrawulan² Emmy Yuanita ${ }^{3 *}$ \\ 1 Fakultas Peternakan, Universitas Mataram, Mataram, Indonesia \\ 2 Fakultas Hukum, Universitas Mataram, Mataram, Indonesia \\ ${ }^{3}$ Fakultas MIPA, Universitas Mataram \\ *emmy_yuanita@unram.ac.id
}

\begin{abstract}
ABSTRAK. Tujuan kegiatan sosialisasi ini adalah masyarakat mampu memanfaatkan limbah dapur agar dapat digunakan sebagai pupuk untuk tanaman, mengingat sebagai besar warga desa jango berprofesi sebagai petani. Disamping itu kegiatan ini bertujuan untuk mengurangi ketergantungan terhadap penggunaan pupuk anorganik yang menggangu kesehatan dan berdampak negative juga terhadap lingkungan. Proses pembuatan pupuk organik cair dapat dilakukan pada berbagai limbah rumah tangga dengan menambkan activator untuk mempercepat proses pembentukan pupuk cair, activator yang digunakan adalah EM4, karena EM4 mengandung Azotobacter sp, Lactobacillus sp, ragi, bakterifotosintetik, dan jamur pengurai selulosa yang berfungsi untuk mempercepat fermentasi bahan organik sehingga unsur hara yang terkandung akan cepat terserap dan tersedia bagi tanaman. Dengan meningkatnya pengetahuan warga terhadap pemanfaatan limbah rumah tangga sebagai bahan pupuk diharapkan berimbas positif bagia warga desa dalam mengurangi limbah dapur serta mengurangi ketergantungan terhadap pupuk anorganik yang lebih lanjut dapat meningkatkan kesejahteraan secara ekonomi dan kesehatan bagi warga desa Jango.
\end{abstract}

Keywords : Pembuatan Pupuk Cair, Pertanian, Kimia dan Organik

\begin{abstract}
The purpose of this socialization activity is that the community is able to utilize kitchen waste so that it can be used as fertilizer for plants, given that most of the villagers work as a farmer. Besides this activity aims to reduce dependence on the use of inorganic fertilizers that interfere with health and also have a negative impact on the environment. The process of making liquid organic fertilizer can be done on a variety of household waste by adding activator to accelerate the process of forming liquid fertilizer, the activator used is EM4, because EM4 contains Azotobacter sp, Lactobacillus sp, yeast, bacteryphotosynthetic, and cellulose decomposing fungi that function to accelerate fermentation organic material so that the nutrients contained will be quickly absorbed and available to plants. With the increasing knowledge of citizens on the use of household waste as fertilizer, it is hoped that this will have a positive impact on villagers in reducing kitchen waste
\end{abstract}


and reducing dependence on inorganic fertilizer which can further improve the economic and health welfare of Jango villagers.

Keywords: Pembuatan Pupuk Cair, Pertanian, Kimia dan Organik

\section{PENDAHULUAN}

Desa Jango merupakan salah satu desa di kecamatan Janapria, kabupaten Lombok Tengah, Nusa Tenggara Barat, dengan luas wilayah 293,73 ha dimana 27.871 Ha terdiri dari sawah dan $5 \mathrm{Ha}$ merupakan perkebunan. Jumlah penduduk Desa Jango ialah sebanyak 2.103 jiwa dengan jumlah kepala keluarga 1.445 yang tersebar di 16 dusun. Jarak tempuh antara Desa Jango dengan Kota Mataram ialah sekitar $53 \mathrm{~km}$. Jika dilihat dari kondisi lingkungan dan letak geografisnya, dimana sebagian besar wilayah didominasi oleh persawahan dan perkebunan serta terletak di daerah dataran tinggi, dapat ditarik kesimpulan bahwa sebagian besar dari penduduk di Desa Jango bermata pencaharian sebagai petani maupun buruh tani. Beberapa kegiatan pertanian yang paling banyak dilakukan di desa ini ialah, penanaman tembakau, padi dan jagung.

Pertanian merupakan kegiatan bercocok tanam dalam mengolah suatu lahan, dengan menanam komoditas-komoditas tertentu untuk memenuhi kebutuhan pangan. Dalam kegiatan pertanian, sangat dibutuhkan suatu keseimbangan dari beberapa faktor yang menompang pertanian tersebut. Indonesia yang seharusnya sebagai negara yang maju di bidang pertanian, pada kenyataannya sangat berbanding terbalik dengan kondisi lahan yang ada di sekitar kita. Hal ini dikarenakan komponen-komponen pendukung untuk meningkatkan kualitas dan kuantitas hasil pertanian tidak berjalan sesuai keinginan, sehingga menyebabkan kondisi pertanian cenderung memprihatinkan.

Komponen-komponen penting dalam suatu kegiatan pertanian itu sendiri adalah pengolahan tanah dan tanamannya. Salah satu pengolahan pertanian yang tidak bisa di lepaskan untuk meningkatkan kualitas dan kuantitas dalam pertanian adalah melalui pemupukan.

Sebagian besar petani mengggunakan pupuk anorganik untuk meningkatkan hasil pertanian, namun dampak dari pemberian pupuk tersebut secara terus menerus oleh petani, mengakibatkan rusaknya lingkungan dan sifat fisik tanah. Penggunaan pupuk dan peptisida sintesis terus-menerus tanpa diimbangi dengan penggunaan pupuk organik akan berdampak pada kesuburan tanah baik secara fisik, kimia, maupun biologi, yang dimana kesuburan tanah secara biologis sangatlah berperan penting dalam bidang pertanian itu sendiri.

Untuk mengurangi kerusakan lahan pertanian sebagai akibat dari pemakaian pupuk an organik oleh petani, mahasiswa/i akan memberikan solusi kepada petani agar menggunakan pupuk organik cair yang kaya unsur hara esensial yang di butuhkan oleh tanaman serta ramah lingkungan, karena mengandung bahan-bahan organik yang baik untuk menjaga kondisi fisik tanah di lahan pertanian.

Pupuk organik cair adalah hasil dari pembusukan bahan-bahan organik yang berasal dari sisa-sisa tanaman, kotoran hewan maupun kotoran manusia yang mengandung unsur hara lebih dari satu unsur. Dengan mengolah sampah organik, seluruh nutriens yang tekandung pada sampah organik tersebut dapat dimanfaatkan, selain itu pengolahan sampah ini juga dapat menyerap mikroorganisme, bakteri, fungi, protozoa, dan nematoda. Pupuk organik cair juga mengandung unsur kalium yang berperan dalam setiap proses metabolisme tanam, yaitu dalam 
sintesis asam amino dan protein dari ion-ion ammonium serta berperan dalam memelihara tekanan turgor dengan baik, sehinga dapat memungkinkan lancarnya proses-proses metabolisme.

Pada pembuatan pupuk organik cair ini diberikan aktivator yaitu EM4, karena EM4 mengandung Azotobacter sp, Lactobacillus sp, ragi, Bacterifotosintetik, dan jamur pengurai sellulosa. Yang mana keunggulan dari EM4 ini adalah akan mempercepat fermentasi bahan organik sehingga unsur hara yang terkandung akan cepat terserap dan tersedia bagi tanaman ( Hadiswito, 2012).

Pada setiap tahunnya ribuan hektar lahan yang subur berkurang akibat penggunaan pupuk kimia karena penggunaan pupuk kimia dapat berpengaruh terhap kesehatan dan daya tahan tubuh, pupuk kimia tersebut mengandung racun yang dapat meningkatkan produksi suatu pangan bagi kehidupan. Sedangkan dalam penggunaan pupuk organik tidak meninggalkan residu yang membahayakan bagi kehidupan. Pengaplikasiannya pun mampu memperkaya sekaligus mengembalikan ketersediaan unsur hara bagi tanah dan tumbuhan dengan aman.

Oleh karena itu perlu untuk kita memahami bagaimana cara menggunakan, membuat serta memanfaatkan limbah rumah tangga maupun lingkungan menjadi pupuk cair sebagai salah satu alternatif untuk menyuburkan tanaman petani.

\section{METODE KEGIATAN}

Kegiatan ini dilakukan selama 14 hari mulai dari tanggal 4 Agustus sampai dengan tanggal 11 Agustus tahun 2019. Adapun tempat dilaksanakannya kegiatan ini yaitu di Desa Jango, Kecamatan Janapria, Lombok Tengah, Nusa Tenggara Barat. Adapun Alat dan Bahan yang digunakan dalam program pembuatan pupuk cair dengan menggunakan limbah dapur ini adalah

Peralatan yang digunakan berupa : Ember, Sutil, Ulekan, Pisau, Talenan, Tempat Fermentasi, Botol, Sarung Tangan, dan Masker. Sedangkan bahan habisa pakai yang diperlukan berupa: Sampah Dapur ( Tauge, Tomat, Kol, Jepang, Bayam ), EM4, Air Gula Merah, Sabut Kelapa, Air Cucian Beras dan Molase.

Metode yang kami terapkandalam pelaksanaan kegiatan ini untuk pembuatan pupuk cair dengan limbah dapur adalah :

1. Observasi

Yaitu kegiatan yang dilakukan dilapangan dengan cara mengamati dan meneliti secara langsung bahan, aat, serta cara kerja atau sistem yang diterapkan di Lembaga Pengembangan Pesantren dan Masyarakat.

2. Wawancara

Meakukan interaksi kepada narasumber untuk mendapatkan informasi lebih jelas dan lengkap.

3. Praktek lapangan

Melakukan kegiatan yang telah dipelajari secara teori dan menerapkan secara langsung dilokasi KKN.

4. Pencatatan

Setelah semua tahap di atas dilakukan, maka dilakukanlah pencatatan untuk semua kegiatan dan dilakukan penyelesaian laporan KKN. 


\section{HASIL DAN PEMBAHASAN}

Program pembuatan pupuk cair yang kami lakukan memerlukan proses yang cukup panjang, karena terlebih dahulu harus mendalami cara pembuatan pupuk cair dari limbah dapur agar dapat memperoleh hasil yang maksimal. Pembuatan pupuk cair dari sampah rumah tangga ini memerlukan berbagai macam bahan tambahan dan pendukung selain sampah dapur itu sendiri, yang paling banyak dibutuhkan tentunya sayuran yang sudah membusuk. Bahan-bahan yang digunakan dalam pembuatan pupuk cair ini memiliki manfaat dan kelebihan diantaranya sebagai berikut :

\section{Air Cucian Beras}

Air cucian beras merupakan bahan organik yang kaya akan kandungan nutrisi. Air cucian beras mengandung beberapa nutrisi yang dibutuhkan tanaman dan dapat membuat tanaman menjadi lebih subur. Selain nutrisi, air cucian beras juga mengandung beberapa jenis bakteri yang bermanfaat untuk tanaman.

Air cucian beras memiliki $90 \%$ karbohidrat yang berupa pati, juga mengandung vitamin, mineral dan protein, $80 \%$ protein beras di sebut protein glutein. Kualitas protein glutein cenderung berupa zat lisin, lisin sendiri merupakan asam amino essensial pembatas. Dari struktur mikrobiologi, air beras juga punya keanekaragaman bakteri antagonis, artinya bisa melawan bakteri jahat/patogen. Juga dapat menginvasi sel telur hama kutu-kutuan menjadi pecah sebelum waktunya. Tak ayal daun yang selalu diaplikasikan dengan air cucian beras sebagai pupuk cair hayati cenderung sehat dan subur.

2. Air Kelapa

Komposisi kandungan zat kimia yang terdapat pada air kelapa antara lain asam askorbat atau vitamin C, protein, lemak, hidrat arang, kalsium atau potassium. Mineral yang terkandung pada air kelapa ialah zat besi, fosfor dan gula yang terdiri dari glukosa, fruktosa dan sukrosa. Kadar air yang terdapat pada buah kelapa sejumlah 95,5 gram dari setiap 100 gram.

Secara khusus, air kelapa kaya akan potasium (kalium). Selain mineral, air kelapa juga mengandung gula (bervariasi antara 1,7 sampai 2,6 persen) dan protein (0,07- 0,55 persen). Karena komposisi gizi yang demikian ini, maka air kelapa berpotensi dijadikan bahan baku produk pangan.

3. EM4 dan Molase

EM4 merupakan singkatan dari Effective Microorganism-4, dimana larutan ini adalah suatu cairan berwarna coklat kekuning-kuningan dan berbau asam yang mengandung berbagai mikroorganisme (bakteri) yang menguntungkan serta bermanfaat bagi kesuburan tanah, dan pertumbuhan tanaman. Adapun bakteribakteri yang terkandung dalam larutan EM4 diantaranya adalah ;Bakteri Fotosintetik (Rhodopseudomonas Sp), Bakteri Asam Laktat (Lactobacillus Sp), ragi/yeast (Saccharomyces Sp) , Actinomycetes Sp, dan jamur pengurai selulose (Aspergillus dan Penicilium).

Molase mengandung konsentrasi terbesar belerang, potasium, besi, dan zat gizi mikro dari bahan tebu asli. Jadi, tidak hanya kandungan gula yang membuat molase berguna, tetapi mineral tersebut. Tetes juga merupakan agen chelating yang sangat baik, yang berarti bahwa itu dapat membantu mengkonversi beberapa nutrisi kimia menjadi bentuk yang mudah tersedia untuk organisme dan tanaman untuk digunakan. Molase blackstrap (unsulphered) adalah molase cair yang dapat 
digunakan sendiri, atau sebagai komponen di kedua semprotan dan drenches tanah, dan dapat menjadi tambahan penting untuk program pemupukan organic.

Berikut adalah proses dari pembuatan pupuk organik cair :

1. Langkah pertama siapkan ember yang besar kemudian masukan air kelapa dan air beras kedalam ember.

2. Kemudian campur Molase 1 liter dengan EM4 1 liter disatukan dengan air kelapa dan air cucian beras yang sudah dicampurkan didalam ember.

3. Setelah itu masukkan bahan-bahan yang sudah dicacah dan dipotong-potong seperti hijauan daun, tauge, bawang merah, labu siam, sabut kelapa.

4. Setelah bahan dicampurkan didalam ember lalu di aduk secara merata.

5. Melakukan fermentasi selama 14 hari dengan cara menuntup rapat menggukan karung.

6. Tahapan terakhir melakukan penyaringan

7. Menambahkan daun pandan yang sudah dipotong kecil-kecil.

\section{Sosialisasi Pembuatan Pupuk Cair}
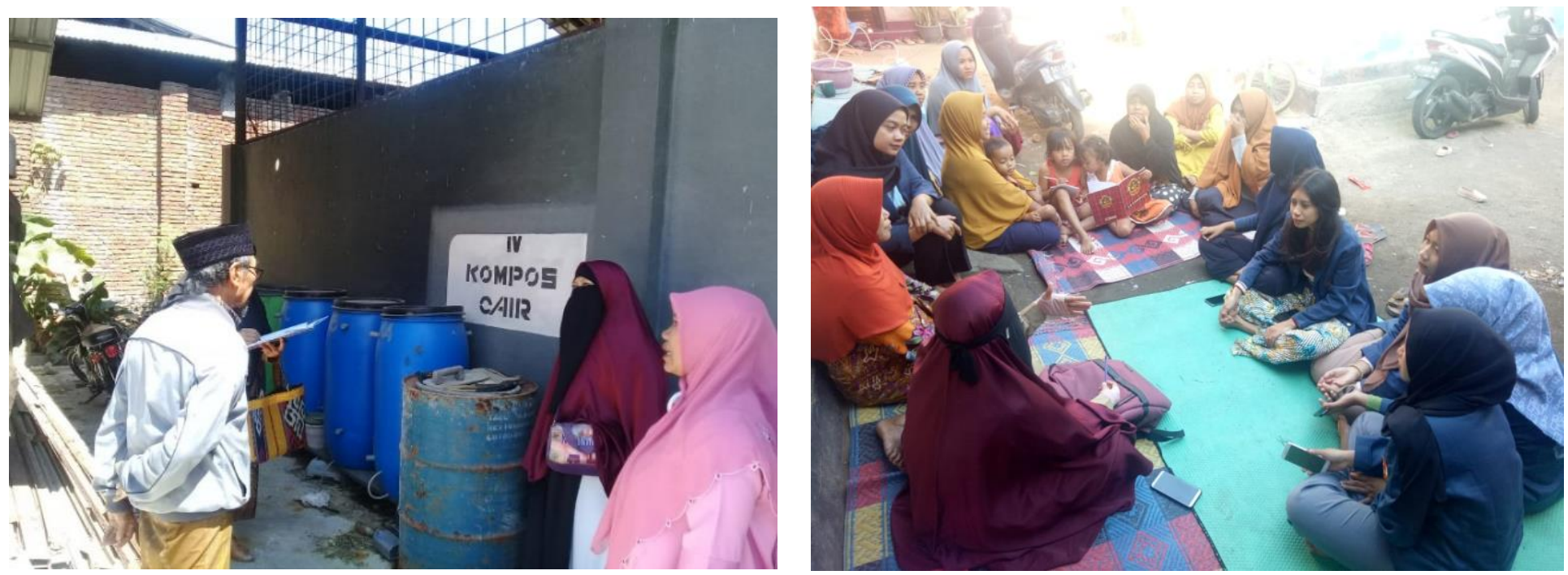
Bahan Pembuatan Pupuk Cair
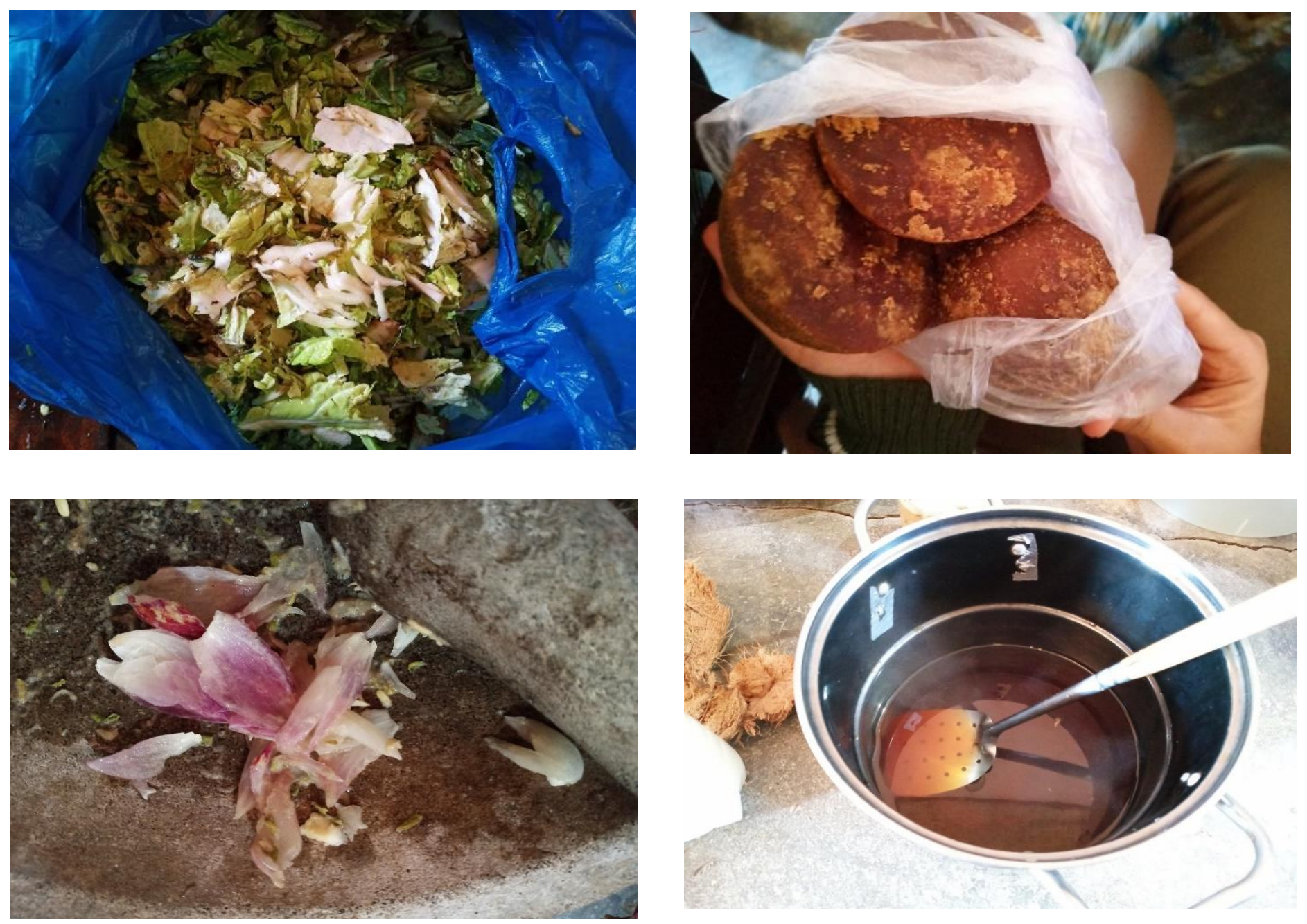

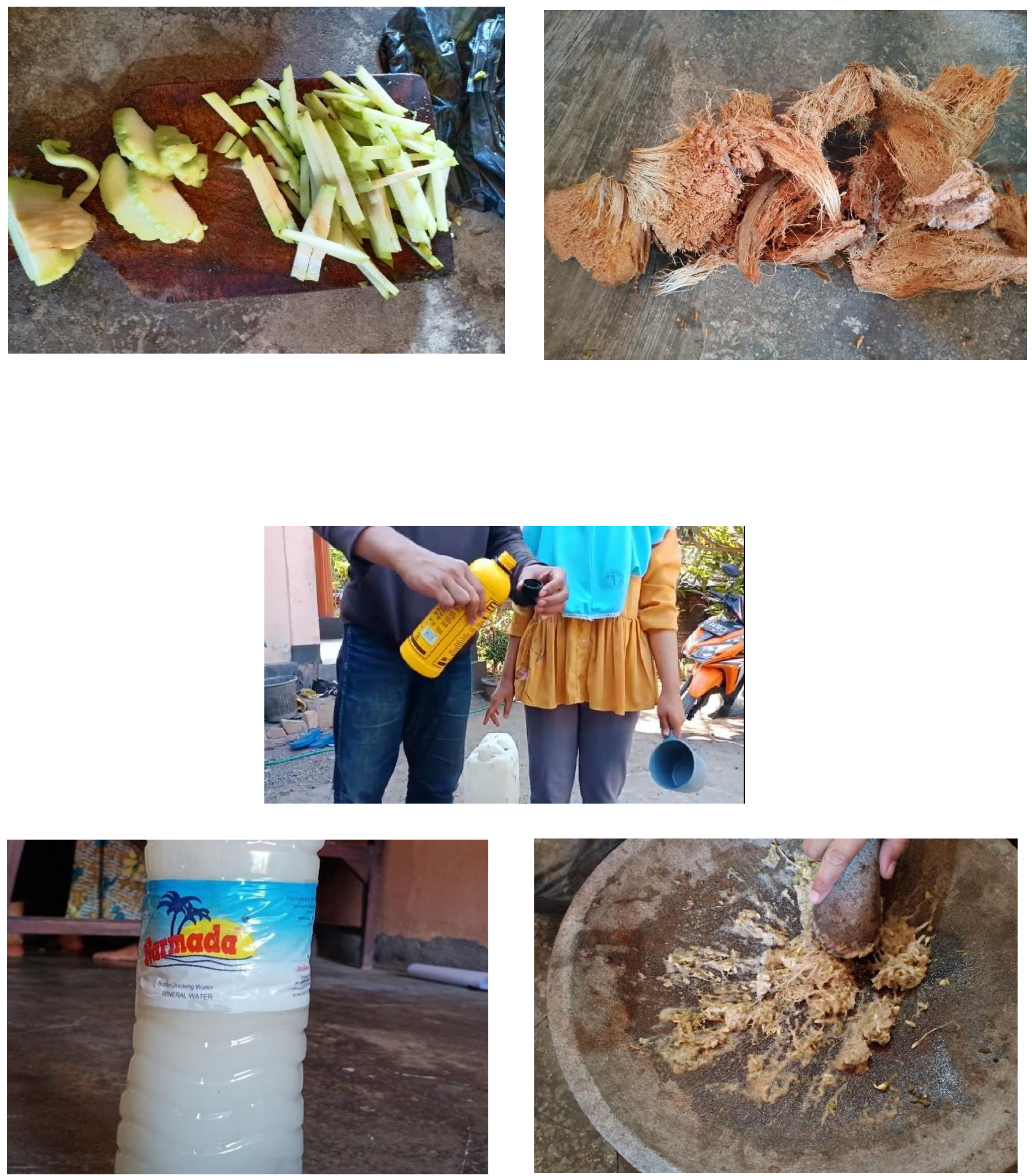


\section{Pembuatan Pupuk Cair}
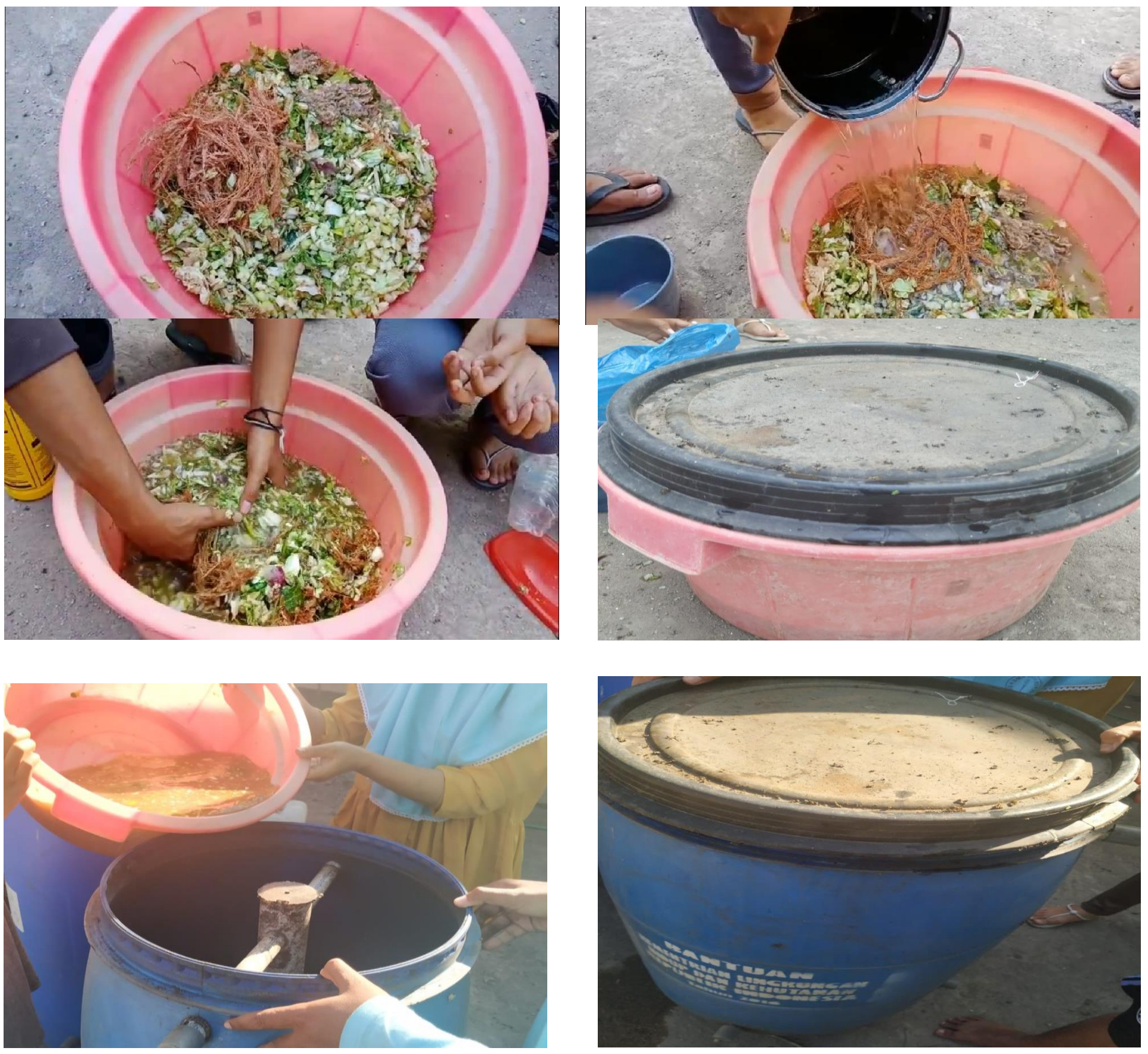

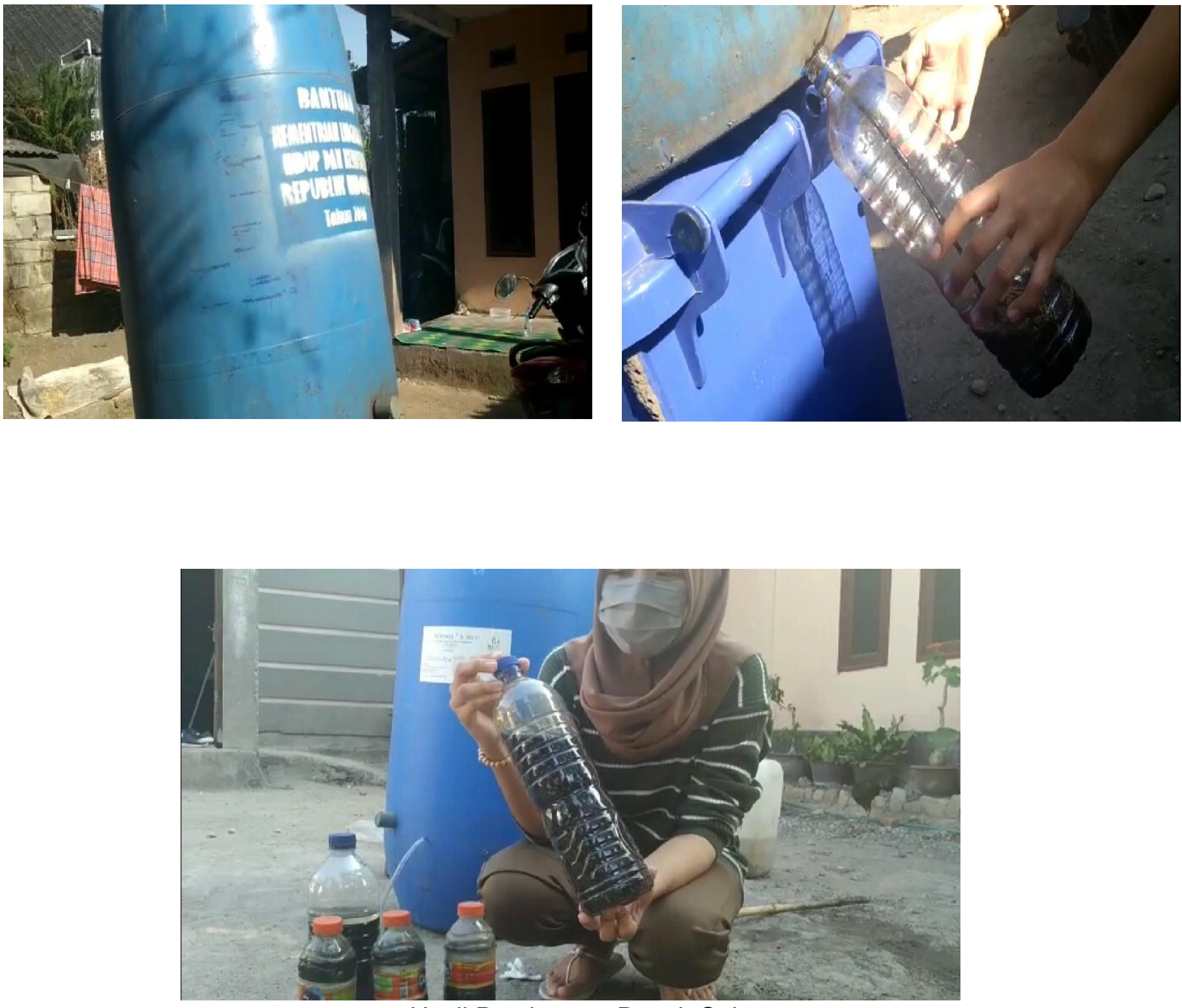

Hasil Pembuatan Pupuk Cair 


\section{KESIMPULAN DAN SARAN}

Kesimpulan dari program ini adalah masyarakat mampu memanfaatkan limbah dapur agar dapat digunakan sebagai pupuk untuk tanaman, dalam hal ini di Desa Jango banyak menanam Tembakau, Padi, dan Jagung, sehingga penggunaan pupuk tersebut dapat dimanfaatkan dengan baik yang akan menguntungkan bagi para petani di Desa Jango itu sendiri, sehingga akan menghasilkan tanaman dengan kualitas baik serta dapat meningkatkan harga jual, selain dapat dimanfaatkan atau digunakan secara pribadi, Pupuk Cair ini dapat pula dipasarkan untuk digunakan dikalangan luas, sehingga hal ini dapat berdampak baik bagi masyarakat Desa Jango.

\section{UCAPAN TERIMAKASIH}

Terimakasih kami ucapkan kepada pihak-pihak yang telah membantu kegiatan sosialisasi pembuatan pupuk cair dari sampah dapur di Desa Jango, sehingga proses ini dapat berjalan dengan baik sehingga program kerja kami dapat terlaksana dan pihak-pihak yang terlibat juga dapat merasakan manfaat dari apa yang kami sosialisasikan

\section{DAFTAR PUSTAKA}

Abbas B. 2011. Prinsip Dasar Kultur Jaringan. Alfabeta, Bandung.

Ayub 2004. Pupuk Organik Cair. Denpasar: Universitas Udayana.

Lizawati, 2012. Proliferasi Kalus dan Embriogenesis Somatik Jarak Pagar ( Jatropha curcas L.) Dengan Berbagai Kombinasi ZPT dan Asam Amino, Jurnal Penelitian 1(4):33-34

Sukirno, Rachman.2002. Penerapan Pertanian Organik. Kanisius: Yogyakarta

Susanto,Rachman. 2002. Penerapan Pertanian Organik. Kanisius: Yogyakarta

Zulkarnain. 2009. Kultur Jaringan Tanaman. Bumi aksar, Jambi 